\title{
PENGARUH PEMBELAJARAN BERBASIS MASALAH TERHADAP PENGUASAAN KONSEP DAN KETERAMPILAN PROSES SAINS SISWA KELAS V
}

\author{
THE EFFECT OF PROBLEM-BASED TEACHING \\ ON THE CONCEPT MASTERY OF SCIENCE AND SCIENCE PROCESS SKILLS \\ OF GRADE V
}

\author{
Ilham Handika, Muhammad Nur Wangid \\ PPs UNY, Universitas Negeri Yogyakarta \\ ilham.handika@yahoo.com,nurwangid2003@yahoo.com
}

\begin{abstract}
Abstrak
Tujuan dari penelitian ini adalah mengetahui pengaruh pembelajaran berbasis masalah terhadap penguasaan konsep sains dan keterampilan proses sains siswa kelas V SD. Penelitian ini merupakan kuasi eksperimen dengan rancangan penelitian Nonequivalent-groups Pretest-Posttest Design. Kelas eksperimen yaitu kelas VB SDN 01 Labuhan Sumbawa $(n=38)$ dengan pembelajaran berbasis masalah dan kelas kontrol yaitu Kelas VA SDN 01 Labuhan Sumbawa $(n=36)$ dengan pembelajaran konvensional. Data dianalisis dengan statistik deskriptif dan MANOVA. Hasil penelitian adalah sebagai berikut. (1) Pembelajaran berbasis masalah berpengaruh signifikan dan lebih baik dibandingkan dengan pembelajaran konvensional terhadap penguasaan konsep sains siswa SD (Sig. $=0.000, p<0.05$ ). (2) Pembelajaran berbasis masalah berpengaruh signifikan dan lebih baik dibandingkan dengan pembelajaran konvensional terhadap keterampilan proses sains siswa SD (Sig. $=0.000, p<0.05)$. Penelitian ini memiliki implikasi bahwa guru harus mulai meninggalkan model pembelajaran konvensional dan beralih ke pembelajaran berbasis masalah dan guru harus dapat menjadi mediator dan fasilitator dalam pembelajaran.
\end{abstract}

Kata kunci: pembelajaran berbasis masalah, penguasaan konsep sains, keterampilan proses sains.

\begin{abstract}
This research is aimed at investigating the effect of problem-based teaching on concept mastery of science and science process skills of grade $V$ students of primary school. This is a quasi experimental research with nonequivalent-groups pretest and posttest design. The experimental class was students of class VB SD Negeri 01 Labuhan Sumbawa $(n=38)$ and control class was students of class VA SD Negeri 01 Labuhan Sumbawa $(n=36)$. The data were analyzed using the descriptive statistics and MANOVA. The result of the research is as follows. (1) Problem-based teaching has a significant effect and better than conventional teaching on students'concept mastery of science (Sig. $=0.000 ; p<0.05)$. (2) Problem-based teaching has a significant effect and better than conventional teaching on students' science process skills (Sig. $=0.00 ; p<0.05$ ). The research findings imply that teachers need to change their teaching model into problem-based teaching and the teachers should become mediators and facilitators in the intructional process.
\end{abstract}

Keywords : problem-based teaching, concept mastery of science and science process skills. 


\section{Pendahuluan}

Pendidikan dasar sebagai pondasi awal dari struktur pendidikan nasional belum menjadi perhatian banyak kalangan. Padahal pendidikan di sekolah dasar akan memberikan modal dan bekal yang sangat penting bagi peserta didik dalam membentuk sikap dan kepribadian di masa yang akan datang. Peserta didik sekolah dasar memiliki kemampuan-kemampuan dasar untuk berkembang secara optimal sesuai dengan bakat dan potensi yang dimilikinya. Proses pembelajaran harus di pandang sebagai stimulus bagi peserta didik untuk melakukan kegiatan belajar yang dibimbing oleh guru. Oleh karena itu, pendidikan di sekolah dasar harus menjadi perhatian semua pihak.

Salah satu wujud perhatian itu adalah adanya tuntutan dari masyarakat terhadap perubahan paradigma pendidikan dan pembelajaran di sekolah dasar. Selama ini, pembelajaran di sekolah dasar masih cenderung berpusat pada guru (teachers oriented), dimana guru menjadi satu-satunya sumber pengetahuan dan peserta didik diibaratkan dengan gelas kosong yang harus diisi dengan pengetahuan dan keterampilan sebanyak-banyaknya. Dengan diberlakukannya KTSP 2006, paradigma pembelajaran di sekolah dasar menjadi berpusat kepada siswa. Perubahan paradigma ini menuntut para guru dan pihak sekolah untuk menciptakan pembelajaran kreatif, inovatif dan berkualitas yang muaranya adalah terbentuknya pribadi peserta didik yang unggul dan mampu bersaing dalam kehidupan bermasyarakat.

Selain itu perubahan paradigma juga dapat dilihat dari metode pengajaran yang digunakan oleh guru. Torp \& Sage (2002, p.15) menyebut paradigma ini yaitu paradigma pembelajaran (Learning paradigm). Lebih lanjut mereka menjelaskan yaitu "teachers use real-world problems as they coach learning through probing, questioning, and challenging student thinking". Artinya guru seharusnya menggunakan masalah yang berasal dari pertanyaan, kemungkinan dan tantangan yang akan dihadapi oleh siswa mereka. Ibaratnya guru dapat memberikan siswa "tangga" untuk mencapai tingkat pengetahuan yang lebih tinggi, namun diupayakan peserta didik sendiri yang menaiki "tangga" tersebut.

Kenyataan di lapangan berbicara lain, pembelajaran khususnya pembelajaran sains masih didominasi oleh pembelajaran konvensional dengan ciri khasnya yaitu pembelajaran berpusat pada guru (teachers oriented). Akibatnya guru menjadi satu-satunya sumber pengetahuan. Guru selalu menggunakan metode yang paling mudah yaitu metode ceramah. Ciri khas dari metode ini ada siswa mendengar, kemudian mencatat apa yang disampaikan guru lalu terakhir menghafal materi tersebut.

Kondisi ini didukung oleh hasil penelitian Pusat Kurikulum Departemen Pendidikan Nasional tahun 2007 yang menyatakan metode ceramah dengan cara menulis di papan tulis merupakan metode yang paling banyak digunakan. Dampak dari penggunaan metode tersebut adalah peserta didik menjadi pasif dimana hanya mendengar penjelasan guru dan mencatat hal-hal yang dianggap penting. Akibatnya terjadi penumpukan konsep dan informasi belaka dalam diri peserta didik. Memang konsep dan materi penting namun yang lebih penting adalah proses yang terjadi di dalam peserta didik bisa memahami konsep atau materi tersebut. Pemahaman yang baik tentang konsep dan materi akan menentukan sikap dan perilaku peserta didik dalam berhadapan dengan masalah kehidupan sehari-hari.

Akibat dari paradigma pembelajaran yang masih berpusat pada guru, kualitas pendidikan di Indonesia masih jauh tertinggal jika dibandingkan dengan negara berkembang lainnya. Hal ini dapat dilihat dari laporan eksekutif Organisasi kerja sama Ekonomi tentang hasil penelitian PISA (Programme for International Student Assessment) tahun 2009 yang menyatakan bahwa kemampuan sains siswa SD Indonesia berada pada urutan ke-60 dari 65 negara anggota peserta PISA 2009.

Dasna dan Sutrisno (Sarino, 2011, p.4) menyatakan salah satu indikator rendahnya kualitas pendidikan kita adalah siswa kurang mampu menyelesaikan permasalahan kontekstual yang dihadapinya. Hal ini disebakan karena proses pembelajaran mentitikberatkan pada penghafalan materi dan prosedur tanpa pernah sekalipun dihadapkan pada kenyataan dilapangan.

Untuk mencapai tujuan pendidikan nasional dan sebagai salah satu upaya untuk meningkatkan kualitas pembelajaran dapat menggunakan inovasi pembelajaran sains yang dewasa ini dikembangkan yaitu Pembelajaran Berbasis Masalah (PBM). Model PBM merupakan model pembelajaran yang lebih menekankan pada pemecahan masalah atau masalah sebagai titik tolak atau dasar dalam proses 
pembelajaran. Widjajanti (2011, p.3) menyatakan bahwa dalam pendekatan berbasis masalah, masalah yang nyata dan kompleks, memotivasi siswa untuk mengidentifikasi dan meneliti konsep dan prinsip yang mereka perlu ketahui untuk berkembang melalui masalah tersebut. Siswa bekerja dalam tim kecil, dan memperoleh, mengomunikasikan, serta memadukan informasi dalam proses yang menyerupai atau mirip dengan menemukan (inquiry).

Holil (2008, p.1) menyatakan bahwa PBM dalam pembelajaran sains merupakan salah satu pembelajaran yang cukup menarik dikarenakan (1) PBM mengajak peserta didik untuk menyelesaikan kasus atau permasalahan yang berkaitan dengan sains, (2) meningkatkan minat diskusi antarpeserta didik dan mendorong kegiatan belajar, (3) membantu siswa mengkonstruksi pengetahuannya tentang dunia di sekitarnya dan mambantu meletakkan pondasi pengetahuan awal mereka sebelum berlanjut ke pengetahuan yang lebih kompleks.

Artikel dalam buletin CIDR (Center for Instructional Development dan Research) (2004, p.1) juga mendukung mengapa PBM digunakan dalam pembelajaran karena: (1) PBM menyiapkan siswa lebih baik untuk menerapkan pembelajaran (belajar) mereka pada situasi dunia nyata; (2) PBM memungkinkan siswa menjadi produsen pengetahuan, dari pada hanya konsumen; dan (3) PBM dapat membantu siswa mengembangkan komunikasi, penalaran, dan ketrampilan berfikir kritis.

Dari pemaparan di atas, dapat dilihat bahwa dalam konteks sejatinya ada kesenjangan dalam proses pembelajaran sains di sekolah dasar. Aspek fundamental dari sains seperti konsep dan keterampilan proses masih dikesampingkan oleh guru dan lebih mengejar terselesaikannya materi. Maka dari itu pentingnya penelitian ini yaitu untuk mengetahui pengaruh pembelajaran berbasis masalah terhadap penguasaan konsep sains dan keterampilan proses sains siswa kelas V sekolah dasar.

Berdasarkan kajian permasalahan maka dapat dibuat suatu hipotesis penelitian yang terdiri dari dua bagian yaitu pertama terdapat pengaruh yang signifikan pembelajaran berbasis masalah dibandingkan dengan pembelajaran konvensional dimana pembelajaran berbasis masalah memiliki pengaruh yang lebih baik dibandingkan dengan pembelajaran konvensional terhadap penguasaan konsep sains siswa kelas V Sekolah Dasar
Adapun hipotesis bagian kedua yaitu terdapat pengaruh yang signifikan pembelajaran berbasis masalah dibandingkan dengan pembelajaran konvensional dimana pembelajaran berbasis masalah memiliki pengaruh yang lebih baik dibandingkan dengan pembelajaran konvensional terhadap keterampilan proses sains siswa kelas $\mathrm{V}$ sekolah dasar

\section{Metode}

Jenis dan Desain Penelitian

Penelitian ini merupakan penelitian kuantitatif dengan pendekatan eksperimen semu. Adapun desain penelitian yang digunakan adalah Nonequivalent-Groups Pretest-Posttest Design.

Tempat dan Waktu Penelitian.

Penelitian dilaksanakan di SD Negeri 01 Labuhan Sumbawa pada tahun ajaran 2012/ 2013 dari bulan Februari sampai Maret 2013

Populasi dan Sampel Penelitian

Populasi penelitian ini adalah seluruh siswa kelas V SD Negeri 01 Labuhan Sumbawa yang berjumlah 74 siswa. Pengambilan sampel dilakukan dengan teknik cluster random sampling. Adapun sampel penelitian adalah kelas $\mathrm{V}_{\mathrm{A}}$ sebagai kelas kontrol dengan 36 siswa dan kelas $\mathrm{V}_{\mathrm{B}}$ sebagai kelas eksperimen dengan 38 siswa.

\section{Teknik dan Instrumen Pengumpulan Data}

Teknik yang digunakan dalam proses pengumpulan data yaitu tes. Tes dilakukan pada saat sebelum perlakuan diberikan yang disebut (pretest) dan pada saat setelah siswa selesai diberikan perlakukan atau disebut (posttest). Adapun instrumen pengumpulan data yaitu tes penguasaan konsep sains dan tes keterampilan proses sains.

\section{Instrumen Pengumpulan Data}

Instrumen yang digunakan dalam penelitian ini adalah:

\section{Tes Penguasaan Konsep.}

Untuk mengetahui penguasaan konsep sains siswa kelas $\mathrm{V}$ maka digunakan instrumen penelitian berupa tes penguasaan konsep sains. Adapun tahapan pengembangan instrumen tes penguasaan konsep sains sebagai berikut: 1) Melihat standar kompetensi dan kompetensi dasar materi yang diberikan yaitu Cahaya.; 2) Menyusun kisi-kisi soal penguasaan konsep 
sains.; 3) Menyusun butir-butir soal berdasarkan kompetensi dasar dan indikator.; 4) Melakukan validasi terhadap instrumen yang telah dibuat dengan meminta bantuan validator ahli yaitu Ibu Dr. Insih Wilujeng, M.Pd dan validator praktisi yaitu Ibu Asminingsih, S.Pd; 5) Melakukan ujicoba instrumen pada kelas yang telah memperoleh materi cahaya.; 6) Estimasi validitas dan reliabilitas instrumen penelitian.; 7) Revisi instrumen penelitian sesuai dengan saran perbaikan.

\section{Tes Keterampilan Proses Sains.}

Untuk mengetahui keterampilan proses sains siswa kelas $\mathrm{V}$ maka digunakan instrumen penelitian berupa tes keterampilan proses sains. Adapun tahapan pengembangan instrumen tes keterampilan proses sains sebagai berikut: 1) Melihat standar kompetensi dan kompetensi dasar materi yang diberikan yaitu Cahaya.; 2) Menyusun kisi-kisi soal keterampilan proses sains.; 3) Menyusun butir-butir soal berdasarkan kompetensi dasar dan indikator; 4) Melakukan validasi terhadap intrumen yang telah dibuat dengan meminta bantuan validator yaitu Ibu Dr. Insih Wilujeng, M.Pd dan validator praktisi yaitu Ibu Asminingsih, S.Pd; 5) Melakukan ujicoba instrumen/butir pada kelas yang telah memperoleh materi cahaya.; 6) Estimasi validitas dan reliabilitas instrumen penelitian.; 7) Revisi instrumen penelitian sesuai dengan saran perbaikan.

Validitas dan Reliabilitas Instrumen

\section{Uji Validitas}

Validitas dibagi menjadi dua yaitu: (1) validitas rasional dan (2) validitas empiris. Untuk mengukur validitas rasional seluruh instrumen menggunakan pendapat ahli atau pakar dibidangnya (expert judgment). Sedangkan untuk uji coba validitas empiris menggunakan uji coba instrumen di lapangan pada kelas uji coba. Untuk instrumen tes penguasaan konsep dan keterampilan proses sains berupa soal tes pilihan ganda.

\section{Uji Reliabilitas}

Reynolds, Livingston \& Wilson (2010, p.91) menyatakan bahwa " Reliability refers to consistency or stability of assesmnet results". Adapun artinya yaitu reliabilitas mengacu pada konsistensi atau keajegan dari hasil suatu pengukuran. Uji reliabilitas menggunakan program SPSS 16.0 for Windows dengan menggunakan rumus dasar formula Alpha Cronbach.

\section{Teknik Analisis Data}

Data yang diperoleh dianalisis melalui tiga tahap, yaitu tahap deskripsi data, tahap uji persyaratan analisis dan tahap pengujian hipotesis.

\section{Tahap Deskripsi Data.}

Langkah yang dilakukan pada tahap deskripsi data ini adalah membuat rangkuman distribusi data pretest dan posttest dari hasil statistik deskriptif program komputer SPSS 16 for Windows.

\section{Tahap Uji Prasyarat Analisis}

Uji prasyarat analisis yang dilakukan uji normalitas, uji homogenitas dan uji kolinearitas data. Uji normalitas data menggunakan uji kolmogorov-smirnov, uji homogenitas menggunakan uji Levene, dan uji kolinearitas dengan menggunakan Uji Regresi Linear dan Uji Korelasi dengan menggunakan program komputer SPSS 16 for Windows.

\section{Tahap Pengujian Hipotesis}

Penelitian ini memiliki dua hipotesis. Untuk menguji kedua hipotesis tersebut menggunakan teknik uji MANOVA. Muijs (2011, p.187) menyatakan bahwa " MANOVA allows us to test hypotheses regarding the effect of one or more independent variables on two or more dependent variables". Artinya MANOVA memberikan kesempatan untuk kita menguji hipotesis dari pengaruh satu atau lebih variabel bebas terhadap dua atau lebih variabel terikat.

\section{Hasil Penelitian dan Pembahasan}

Data hasil peneltian untuk pretest disa-jikan dalam Tabel 1 di bawah ini:

Tabel 1. Data Pretest Penguasaan Konsep Sains dan Keterampilan Proses Sains

\begin{tabular}{clcc}
\hline \multirow{2}{*}{ Kelas } & Nilai & $\begin{array}{c}\text { Penguasan } \\
\text { Konsep } \\
\text { Sains }\end{array}$ & $\begin{array}{c}\text { Keteram- } \\
\text { pilan } \\
\text { Proses } \\
\text { Sains }\end{array}$ \\
\hline \multirow{3}{*}{ Eksperimen } & Maksimal & 72,00 & 64,00 \\
& Minimal & 24,00 & 24,00 \\
& Rata-rata & 43,42 & 40,10 \\
& Maksimal & 68,00 & 20,00 \\
Kontrol & Minimal & 20,00 & 60,00 \\
& Rata-rata & 39,44 & 39,22 \\
\hline
\end{tabular}


Berdasarkan Tabel 1 dapat dilihat untuk kelas eksperimen pada variabel penguasaan konsep sains diperoleh nilai maksimal yaitu 72,00 dan nilai minimal 24,00. Adapun rataratanya yaitu 43,42. Sedang untuk variabel keterampilan proses sains didapatkan nilai maksimal yaitu 64,00 dan nilai minimal yaitu 24,00 dengan nilai rata-ratanya yaitu 40,10.

Dari Tabel 1 juga dapat dilihat data pretest untuk kelas kontrol. Untuk variabel penguasaan konsep sains diperoleh nilai maksimal yaitu 68,00 dan nilai minimal yaitu 20,00 dengan rata rata yaitu 39,44. Sedang untuk variabel keterampilan proses sains didapatkan nilai maksimal yaitu 60,00 dan nilai minimal 20,00. Adapun nilai rata-ratanya yaitu 39,22.

Data hasil posttest penelitian disajikan pada Tabel 2 di bawah ini.

Tabel 2. Data Posttest Penguasaan Konsep Sains dan Keterampilan Proses Sains.

\begin{tabular}{clcc}
\hline \multirow{2}{*}{ Kelas } & Nilai & $\begin{array}{c}\text { Penguasan } \\
\text { Konsep } \\
\text { Sains }\end{array}$ & $\begin{array}{c}\text { Keterampilan } \\
\text { Proses Sains }\end{array}$ \\
\hline \multirow{3}{*}{ Eksperimen } & Maksimal & 88,00 & 96,00 \\
& Minimal & 52,00 & 56,00 \\
& Rata-rata & 68,78 & 71,57 \\
Kontrol & Maksimal & 76,00 & 76,00 \\
& Minimal & 40,00 & 40,00 \\
& Rata-rata & 54,50 & 55,44 \\
\hline
\end{tabular}

Berdasarkan Tabel 2 dapat dilihat untuk kelas eksperimen pada variabel penguasaan konsep sains diperoleh nilai maksimal yaitu 88,00 dan nilai minimal 52,00. Adapun rataratanya yaitu 68,78. Sedang untuk variabel keterampilan proses sains didapatkan nilai maksimal yaitu 96,00 dan nilai minimal yaitu 56,00 dengan nilai rata-ratanya yaitu 71,57.

Dari Tabel 2 juga dapat dilihat data posttest untuk kelas kontrol. Untuk variabel penguasaan konsep sains diperoleh nilai maksimal yaitu 76,00 dan nilai minimal yaitu 40,00 dengan rata rata yaitu 54,50. Sedang untuk variabel keterampilan proses sains didapatkan nilai maksimal yaitu 76,00 dan nilai minimal 40,00. Adapun nilai rata-ratanya yaitu 55,44.

Analisis Data

\section{Uji Prasyarat Analisis}

Adapun uji prasyarat meliputi uji normalitas, uji homogenitas dan uji kolinearitas data.

\section{Uji Normalitas Populasi.}

Uji normalitas populasi dilakukan untuk mengetahui apakah data hasil tes yang telah dilakukan terdistribusi normal atau tidak. Uji normalitas dilakukan pada semua data baik di kelas eksperimen maupun kelas kontrol. Pengujian normalitas menggunakan metode Kolmogorov-Smirnov menggunakan program SPSS 16 for Windows.

Tabel 3 berikut menyajikan rangkuman uji normalitas pada KE maupun KK dengan metode Kolmogorov-Smirnov menggunakan program SPSS 16 for Windows. Rangkuman uji normalitas ditunjukkan pada Tabel 3.

Tabel 3. Rangkuman Uji Normalitas pada KE dan KK.

\begin{tabular}{lccccc}
\hline & \multicolumn{4}{c}{ Siginifikansi Kolgomorov- } & \\
\multirow{2}{*}{ Var } & \multicolumn{4}{c}{ Smirnov } & \multirow{2}{*}{ Ket } \\
\cline { 2 - 5 } & Eksperimen & \multicolumn{2}{c}{ Kontrol } & \\
\cline { 2 - 5 } & Awal & Akhir & Awal & akhir & \\
\hline PK & 0,872 & 1,194 & 1,28 & 0,737 & Normal \\
KPS & 0,565 & 0,875 & 0,89 & 1,270 & Normal \\
\hline
\end{tabular}

Dari Tabel 3 dapat dilihat bahwa uji normalitas data awal tes penguasaan konsep IPA untuk kelas eksperimen (KE) dan kelas kontrol (KK) diperoleh nilai siginifikansi 0,872 dan 1,282 dimana lebih tinggi dari nilai alpha yang ditetapkan yaitu 0,05 . Jadi dapat disimpulkan bahwa nilai pretest penguasaan konsep IPA baik pada KE dan KK terdistribusi normal. Demikian halnya dengan nilai awal keterampilan proses IPA dimana diperoleh nilai signifikansi untuk kelas eksperimen adalah 0,565 dan kelas kontrol 0,894. Kedua nilai ini lebih tinggi dari nilai alpha yang ditetapkan yaitu 0,05 , jadi dapat disimpulkan bahwa nilai pretest keterampilan proses IPA baik pada KE maupun KK terdistribusi normal.

Berdasarkan Tabel 3 juga dapat dilihat hasil uji normalitas untuk data akhir baik pada KE maupun KK. Untuk tes akhir penguasaan konsep IPA diperoleh nilai signifikansi pada KE yaitu 1,184 sedangkan KK yaitu 0,737. Kedua nilai signifikansi ini lebih tinggi dari nilai alpha yang ditetapkan yaitu 0,05 , jadi dapat disimpulkan bahwa nilai akhir penguasaan konsep IPA baik pada KE dan KK terdistribusi normal. Demikian halnya dengan nilai akhir keterampilan proses IPA. Dari tabel di atas dapat dilihat nilai signifikansi untuk KE yaitu 0,875 sedangkan KK yaitu 1,270 . Kedua nilai ini lebih tinggi dari nilai alpha yang ditetapkan yaitu 0,05 , jadi dapat disimpulkan bahwa nilai 
akhir keterampilan proses IPA baik pada KE dan KK terdistribusi normal.

\section{Uji Homogenitas Data}

Pengujian homogenitas dilakukan dengan metode uji homogenitas Lavene's dengan program SPSS 16 for Windows. Uji homogenitas digunakan untuk mengetahui data sebelum dan sesudah perlakukan apakah mempunyai varians yang sama atau tidak.

Rangkuman uji homogenitas ditunjukkan pada Tabel 4.

Tabel 4. Rangkuman Uji Homogenitas Data Sebelum dan Sesudah Perlakuan.

\begin{tabular}{lccc}
\hline \multirow{2}{*}{ Variabel } & \multicolumn{2}{c}{ Siginifikansi Levene's } & \\
\cline { 2 - 3 } & $\begin{array}{c}\text { Sebelum } \\
\text { Perlakuan }\end{array}$ & $\begin{array}{c}\text { Setelah } \\
\text { Perlakuan }\end{array}$ & Ket. \\
\hline PK & 0,085 & 0,076 & Homogen \\
KPS & 0,098 & 0,570 & Homogen \\
\hline
\end{tabular}

Berdasarkan Tabel 4 dapat dilihat bahwa nilai signifikansi Levene's untuk variabel Penguasaan konsep IPA sebelum perlakuan adalah 0,085. Nilai ini lebih besar dari harga alpha yang ditetapkan yaitu 0,05 , jadi dapat dikatakan bahwa data pretest penguasaan konsep IPA baik pada KE dan KK adalah homogen. Selanjutnya untuk data setelah perlakuan diperoleh nilai signifikansi 0,098 dimana nilai ini lebih dari harga alpha yang ditetapkan yaitu 0,05 , jadi dapat disimpulkan bahwa nilai posttest baik pada KE dan KK adalah homogen.

Dari Tabel 4 dapat dilihat bahwa untuk variabel keterampilan proses IPA, sebelum perlakukan diperoleh nilai siginifikan yaitu 0,076. Nilai ini lebih tinggi dari harga alpha yang ditetapkan yaitu 0,05 , jadi dapat disimpulkan bahwa data pretest keterampilan proses IPA baik pada KE dan KK adalah homogen. Demikian halnya dengan nilai signifikansi setelah perlakukan diperoleh angka yaitu 0,570. Harga ini lebih tinggi dari harga alpha yang ditetapkan yaitu 0,05 , jadi dapat disimpulkan bahwa data posttest keterampilan proses IPA baik untuk KE dan KK adalah homogen.

\section{Uji Kolinearitas Data}

Penggunaan uji kolinearitas dalam penelitian ini dimaksudkan untuk menentukan hubungan antara dua variabel terikat baik pada kelas eksperimen maupun kelas kontrol sebagai prasyarat uji MANOVA. Uji kolinearitas sangat penting dilakukan untuk melihat apakah benar dua variabel terikat tidak memiliki hu- bungan yang linear dengan dengan variabel bebas.

Kriteria yang digunakan adalah: 1) jika nilai VIF (variance inflation factor) di sekitar angka 1 atau memiliki toerance mendekati 1, maka dikatakan tidak terdapat masalah kolinieritas dalam model regresi; 2) jika koefisien korelasi antarvariabel bebas kurang dari 0,8 maka tidak terdapat masalah kolinieritas.

Dari hasil perhitungan menggunakan SPPS 16 for Windows diperoleh nilai VIF yaitu 1 dan nilai korelasi antarvariabel terikatnya yaitu 0,760. Angka korelasi ini lebih kecil dari 0,8 , jadi dapat dikatakan bahwa antara nilai penguasaan konsep sains dan keterampilan proses sains tidak terjadi kolinearitas. Jadi uji MANOVA bisa dilanjutkan.

Pengujian Hipotesis.

Berdasarkan hasil uji prasyarat yang telah dilakukan di atas ditemukan bahwa data penelitian baik untuk pretest dan posttest terdistribusi normal dan variansi antarkelompok homogen. Jadi analisis data dapat dilanjutkan ke pengujian hipotesis.

\section{Uji Hipotesis Pertama}

Uji hipotesis pertama menggunakan nilai posttest penguasaan konsep IPA pada kelas eksperimen dan kelas kontrol. Tujuan dari uji ini adalah untuk mengetahui pengaruh pembelajaran berbasis masalah terhadap variabel terikat yaitu penguasaan konsep IPA siswa. Teknik pengujian hipotesis ini menggunakan MANOVA menggunakan bantuan program SPSS 16 for Windows. Dari hasil output perhitungan diperoleh nilai signifikansi sebesar 0,000. Karena signifikansi kurang dari harga alpha yang ditetapkan yaitu 0,05, artinya ada perbedaan rata-rata kelas eksperimen dan kelas kontrol maka Ho ditolak dan Ha diterima. Jadi dapat dikatakan bahwa ada pengaruh yang signifikan pembelajaran berbasis masalah terhadap penguasaan konsep sains siswa.

Tabel 5. Rangkuman Hasil Uji Manova untuk Variabel Penguasaan Konsep Sains pada Kelas Eksperimen dan Kelas Kontrol.

\begin{tabular}{cclc}
\hline Variabel & F & df & Sig. \\
\hline Penguasaan Konsep Sains & 30,55 & 1 & 0,000 \\
\hline
\end{tabular}

\section{Uji Hipotesis Kedua}

Uji hipotesis kedua menggunakan nilai posttest keterampilan proses IPA pada kelas eksperimen dan kelas kontrol. Tujuan dari uji ini adalah untuk mengetahui pengaruh pembel- 
ajaran berbasis masalah terhadap variabel terikat yaitu keterampilan proses IPA siswa. Teknik pengujian hipotesis ini menggunakan $U j i$ MANOVA menggunakan bantuan program SPSS 16 for Windows. Dari hasil output perhitungan diperoleh nilai signifikansi sebesar 0,000 . Karena signifikansi kurang dari harga alpha yang ditetapkan yaitu 0,05 , artinya ada perbedaan rata-rata kelas eksperimen dan kelas kontrol maka Ho ditolak dan Ha diterima. Jadi dapat dikatakan bahwa ada pengaruh yang signifikan pembelajaran berbasis masalah terhadap keterampilan proses sains siswa.

Tabel 6. Rangkuman Hasil Analisis Uji Manova untuk Variabel Keterampilan Proses Sains pada Kelas Eksperimen dan Kelas Kontrol.

\begin{tabular}{cclc}
\hline Variabel & F & df & Sig. \\
\hline Keterampilan Proses Sains & 30,39 & 1 & 0,000 \\
\hline
\end{tabular}

\section{Pembahasan}

Tujuan dari penelitian ini adalah untuk melihat pengaruh dari pembelajaran berbasis masalah terhadap penguasaan konsep IPA dan keterampilan proses IPA siswa kelas V SD Negeri 1 Labuhan Sumbawa. Untuk mencapai tujuan ini diperlukan deskripsi dan analisis data sehingga bisa ditarik kesimpulan yang tepat mengenai pengaruh dari pembelajaran berbasis masalah ini.

Pengaruh Pembelajaran Berbasis Masalah terhadap Penguasaan Konsep IPA

Untuk mengetahui ada tidaknya pengaruh pembelajaran berbasis masalah terhadap penguasan konsep IPA maka harus dipastikan bahwa kemampuan awal siswa pada kedua kelas baik kelas eksperimen adalah sama. Untuk tujuan ini maka diperlukan uji homogenitas. Berdasarkan hasil uji homogenitas pretest disimpulkan bahwa kemampuan awal siswa baik pada kelas eksperimen dan kelas kontrol adalah sama.

Selanjutnya berdasarkan nilai dan hasil analisis data posttest terhadap kemampuan penguasaan konsep IPA tentang cahaya, siswa yang mendapatkan pembelajaran berbasis masalah menunjukkan bahwa secara keseluruhan kemampuan penguasaan konsep IPA tentang cahaya lebih baik dibandingkan dengan kelas kontrol yang mendapatkan pembelajaran konvensional. Hal ini dapat dilihat dari perbedaan rata-rata nilai akhir kedua kelas dimana kelas eksperimen memperoleh rata-rata nilai posttest sebesar 68,78 sedangkan kelas kontrol hanya sebesar 54,50. Secara sekilas sudah dapat terlihat bahwa pembelajaran berbasis masalah memberikan pengaruh yang lebih baik bila dibandingkan dengan pembelajaran konvensional terhadap kemampuan penguasaan konsep IPA tentang cahaya pada siswa. Untuk membuktikan lebih jauh secara statistik maka dilakukan uji hipotesis menggunakan eknik MANOVA. Dari hasil perhitungan menggunakan MANOVA diperoleh nilai signifikansi 0,000, angka ini jauh dibawah nilai alpha yang ditetapkan yaitu 0,05 sehingga dapat disimpulkan bahwa ada pengaruh yang signifikan pembelajaran berbasis masalah terhadap kemampuan penguasaan konsep IPA siswa.

Kesimpulan ini disebabkan karena dalam pembelajaran berbasis masalah memberi peluang kepada siswa untuk lebih leluasa belajar secara mandiri, saling bertukar pikiran dengan teman dikelompokkan dan saling membantu dalam menyelesaikan tugas atau LKS yang diberikan guru.

Hal ini sejalan dengan kesimpulan dari penelitian yang dilakukan oleh Maria Angelica Pease tahun 2009 dari Colombia University yang menyatakan bahwa "students' superior mastery of the concept learned via PBL in terms of understanding, integration and application". Artinya siswa memiliki kemampuan yang sangat tinggi dalam penguasaan konsep terutatama dalam pemahaman, integrasi dan aplikasi. Pease (2009, p.78) menyatakan bahwa siswa yang diajarkan dengan pembelajaran berbasis masalah baik secara individu maupun tim akan menampilkan kemampuan yang lebih baik dalam hal konsep dan hasil pembelajaran. Jadi dapat dikatakan bahwa penguasaan konsep siswa akan lebih berkembang jika diajarkan dengan metode pembelajaran berbasis masalah dibandingkan dengan pembelajaran konvensional.

Pengaruh Pembelajaran Berbasis Masalah terhadap Keterampilan Proses IPA

Berdasarkan hasil uji homogenitas nilai pretest keterampilan proses IPA baik pada kelas eksperimen maupun kelas kontrol didapatkan kesimpulan bahwa tidak terdapat perbedaan yang signifikan kemampuan keterampilan proses IPA baik pada kelas eksperimen maupun kelas kontrol sebelum diberikan pembelajaran berbasis masalah. Dengan demikian dapat dikatakan bahwa kedua kelas memiliki kemampuan yang sama. 
Berdasarkan hasil analisis posttest kemampuan keterampilan proses IPA pada kelas eksperimen dan kelas kontrol diperoleh nilai rata-rata posttest untuk kelas eksperimen yaitu 71,57 sedangkan untuk rata-rata kelas kontrol yaitu 54,44. Perbedaan ini menujukkan bahwa terdapat perbedaan pengaruh pembelajaran berbasis masalah dan pembelajaran konvensional terhdap kemampuan keterampilan proses IPA siswa. Pengujian selanjutnya menggunakan teknik uji MANOVA untuk mengetahui bagaimana pengaruh pembelajaran berbasis masalah terhadap keterampilan proses IPA.

Hasil pengujian dengan teknik MANOVA menghasilkan nilai signifikansi 0,000 , hasil ini jauh dibawah harga alpha yang ditetapkan yaitu 0,05 . Jadi dapat disimpulkan bahwa ada pengaruh yang signifikan pembelajaran berbasis masalah terhadap keterampilan proses IPA siswa.

Temuan ini menunjukkan bahwa pembelajaran berbasis masalah memberikan pengaruh positif atau lebih baik dalam meningkatkan keterampilan proses sains siswa. Dalam pembelajaran berbasis masalah, siswa diberikan kebebasan berpikir untuk mencari solusi dari masalah yang diberikan guru. Keterampilan proses atau keterampilan beripikir tingkat tinggi lainnya dikembangkan sedemikian rupa dalam pembelajaran berbasis masalah. Siswa mencari solusi dari masalah yang diberikan melalui keterampilan proses sedemikian rupa yang difasilitasi oleh guru. Keadaan ini juga didukung oleh temuan hasil penelitian dari Cinar \& Bayraktar dari Selcuk Univesity, Turkey tahun 2006 yang berjudul The Effects of The Problem Based Learning Approach On Higher Order Thinking Skills in Elementary Science Education yang menyimpulkan "problem-based learning problem was found to be more successful than traditional instruction in improving problem solving and science process skills". Artinya bahwa pembelajaran berbasis masalah ditemukan lebih sukses dibandingkan dengan pembelajaran tradisional/ konvensional dalam meningkatkan kemampuan pemecahan masalah dan keterampilan proses sains.

Penelitian lain yang mendukung hasil temuan ini yaitu penelitian dari Edidiong Enyeneokpon Ukoh tahun 2012 yang berjudul Determining The Effect of Problem-Based Learning Instructional Strategy on Nce PreService Teachers' Achievement In Physics And
Acquisition Of Science Process Skills yang menyimpulkan bahwa "problem-based learning strategy improves students' achievement in physics and acquisition of science process skills and is therefore recommended for use by lecturers in colleges of education". Artinya adalah pembelajaran berbasis masalah meningkatkan prestasi Fisika dan keterampilan proses sains siswa dan selanjutnya direkomendasikan kepada guru/dosen untuk menggunakan PBM dalam pembelajaran.

Hasil temuan dari penelitian ini dan dukungan fakta empiris menyatakan bahwa pembelajaran berbasis masalah memberikan pengaruh yang lebih baik dan secara signifikan meningkatkan keterampilan proses sains siswa sekolah dasar. Temuan ini menuntut para guru untuk menyajikan masalah yang mampu meningkatkan rasa keingintahuan guru. Masalahmasalah dapat diperoleh dari lingkungan sekitar maupun digali dari pengalaman siswa sendiri. Masalah yang diberikan terdapat di dalam LKS kemudian siswa secara bersamasama mencari solusi dari masalah melalui tahapan keterampilan proses yang ada. Dengan pembelajaran berbasis masalah ini, guru diharapkan mampu mengembangkan ide kreativitasnya untuk meningkatkan mutu dan hasil pembelajaran.

\section{Simpulan dan Saran}

Simpulan

Pembelajaran berbasis masalah memberikan pengaruh yang lebih baik dan signifikan dibandingkan dengan pembelajaran konvensional terhadap penguasaan konsep sains dalam hal kemampuan kognitif siswa sekolah dasar. Hal ini ditunjukkan dengan nilai sig. = 0,000 lebih kecil dari nilai alpha yang ditetapkan yaitu $\alpha=0,05$

Pembelajaran berbasis masalah memberikan pengaruh yang lebih baik dan signifikan terhadap keterampilan proses sains siswa dalam hal mengamati, mengelompokkan, mengukur/menghitung, memprediksi, menyimpulkan dan mengkomunikasikan. Simpulan ini dibuktikan dengan nilai sig. $=0,000$ lebih kecil dari nilai alpha yang ditentukan sebesar $\alpha=0,05$.

Saran

Berdasarkan kesimpulan maka saran yang dapat disampaikan adalah: 1) Guru sebaiknya lebih memilih menggunakan pem- 
belajaran berbasis masalah dalam proses pembelajaran khususnya pada materi cahaya dibandingkan dengan pembelajaran konvensional, mengingat berbagai macam keunggulan dari model tersebut.; 2) Perlu persiapan yang lebih baik sebelum melaksanakan pembelajaran berbasis masalah agar hasil dan proses pembelajaran sehingga pembelajaran menjadi maksimal.; 3) Untuk penelitian lebih lanjut, dapat melakukan penelitian untuk mengetahui pengaruh pembelajaran berbasis masalah pada aspek-aspek pembelajaran yang lainnya.

\section{Daftar Pustaka}

Arends, R.I. (2008). Learning to teach (Seventh Edition). New York : McGraw Hill Companies.

CIDR Teaching and Learning Bulletin. (2004). Problem-based learning. Vol. 7 No. 3. Diambil pada 26 November 2012 dari http://depts.washington.edu/cidrweb/Bulle tin/PBL.html

Cheong, F. (2008). Using a problem-based learning approach to teach an intelli-gent systems course. Jurnal of Information Technology Education. Diambil tanggal 2 Desember 2012 dari http://csited.org/ 2007/7CheoCSITEd.pdf

Cinar, D \& Bayraktar, S. (2006). The effects of the problem based learning approach on higher order thinking skills in elementary science education. Diambil pada tanggal 17 Juni 2013 dari http://www.academia.edu/489739/the_effects_of_the_probl em_based_learning_approach_on_higher_ order_thinking_skills_in_elementary_scie nce_education.

Collette, A.T. \& Chiapetta, E.L. (1994). Science instruction in the middle and secondary schools (third edition). New York: Mc Milan Publishing Company.

Holil, A. (2008). Menjadi manusia pembelajar (pembelajaran berbasis masalah). Diambil pada tanggal 12 Juli 2012 dari http://www.garduguru.com/holil?html/

Lee, C.L \& Ward, J.D (2002). A review of problem-based learning. Journal of Family and Consumer Sciences Education, Vol. 20, No. 1, Spring/Summer, 2002.
Muijs, D. (2011). Doing quantitative research in education with SPSS. London: Sage Publication Ltd.

Pease, M.A. (2009). Experimental investigation of the effectiveness of problem-based learning. Diambil pada 30 April 2013 dari http://search.proquest.com/docview/304864773?accountid=31324

PISA International Results. (2009) Pisa 2009. Diambil tanggal 30 November 2012 dari http://www.oecd.org/pisa/46643-496.pdf

Reynolds, C.R, Livingston, R.B \& Wilson, V. (2010). Measuremnet and assessment in education. New Jersey: Pearson Education

Sarino. (2011). Dampak pembelajaran berbasis masalah (problem based learning) terhadap peningkatan motivasi belajar dan prestasi belajar sains siswa : studi eksperimen semu pada materi daur air di Kelas V Sekolah Dasar Negeri 008 Sagulung Kota Batam Provinsi Kepulauan Riau. Tesis Magister, tidak diterbitkan, Universitas Pendidikan Indonesia, Bandung.

Tan, Oon-Seng. (2009). Problem based learning and creativity. Singapore: Cenhage Learning Asia Pte Ltd.

Trianto. (2010). Mendesain model pembelajaran inovatif-progresif. Jakarta: Kencana Prenanda Media.

Torp, L \& Sage, S. (2002). Problems as possibilities :problem-based learning for K-16 education. Virginia: Associa-tion for Supervision and Curriculum Development (ASCD).

Ukoh, E.E (2012). Determining the effect of problem-based learning instructional strategy on nce pre-service teachers' achievement in physics and acquisition of science process skills. Diambil pada tanggal 16 Juni 2013 dari http://eujournal.org/index.php/esj/article/view/271.

Widjajanti, D.B. (2011). Problem based learning dan contoh implementasinya. Yogyakarta. Jurusan Pendidikan Matematika FMIPA UNY 